\title{
ENVIRONMENTAL POLLUTION WITH COPPER AND ITS EFFECTS ON CATTLE IN SHARKIA GOVERNORATE
}

\author{
Anwaar, M. Abdel-Azeem and ${ }^{*}$ Attia, $H$. \\ Biochemistry Dept. Animal Health Research Institute, Zagazig Branch. \\ *Animal Medicine Dept. Faculty of Veterinary Medicine, Zagazig University.
}

\begin{abstract}
In recent years, industrial pollution to water, soil and plants is getting to be toxic and very harmful to the animal and human life. In this study, Seventy adult cattle over 4 years old collected from a private farms adjacent to industrial areas of copper smelters in Sharkia province. These Cows also kept grassing for several years on a Fields and pastures which was previously sprayed and treated with antifungals and other insecticides containing 8\% copper sulphate. Thirty five of the livestock (50\%) showed clinical signs of chronic copper poisoning in the farm of loss appetite, emaciation, diarrhoea, haematuria and jaundice. Five of the diseased cows were emergency slaughtered. Water, soil, Feedstuffs, blood and tissues samples were collected and revealed a high concentration of copper than the recommended permissible limits of WHO (1995). The copper poisoning influenced the serum biochemical constituents showning a significant increase in the levels of serum alanine aminotransferase (S.ALT), aspartate aminotranferase (S.AST), serum alkaline pohsphatase enzyme (S.AP) zinc, iron urea and creatinine, while there were a highly significant decrease of serum total protein, albumin, sodium and potassium. Haematological studies showed normocytic normochromic anaemia represented by significant decrease of redblood cells count (RBCs), haemoglobin content ( $\mathrm{Hb}$ ) and Packed cell volume (PCV) accompanied by leucocytosis. The public health hazard toxic effects of copper residues for animals and human was discussed and suggestive recommendations to protect consumers were recorded.
\end{abstract}




\section{INTRODUCTION}

Environmental pollution with heavy metals mostly occurs near smelters and other industrial enterprises, where soil, water and plants are liable to be contaminated with wasted fumes and emissions, giving rise to a great ecological significant due to their toxicity and accumulation behavior. Copper salts are used widely in agriculture and veterinary practice where most cases of chronic copper poisoning occurred in Farm animals grassing in Fields and pastures previously sprayed with insecticides or Fungicides containing copper sulphate (Clark and Clark, 1985). Also copper salts are used as mollousccides for destroying the snails of fasciola and Sehistosoma in rivers and water streams in eradication programs. Moreover, continuous fortifying the cultivated soil with fertilizers containing copper phosphate raises the copper levels in soil and plants or grasses. The long term exposure of dairy cattle to polluted air, water and plants through intestinal absorption raised blood copper levels associated with increased accumulation of copper residues in muscles, liver and kidneys resulting in liver and kidney dysfunction, followed by the appearance of clinical signs of chronic copper poisoning including general weakness, anorexia, haemoglobinuria and icterus (Omran, 1997 and Radostits et al. 2002). Liver and kidney damage due to chronic copper poisoning evidenced marked changes in serum biochemical and haematological parameters (Schwarz, et al. 2004).

The present investigation was carried out to study the effect of chronic copper poisoning on the healthy status of cattle blood and tissues in addition to serum biochemical and haematological changes associated with it. 


\section{MATERIALS AND METHODS}

\section{Animals:}

Seventy adult cattle, over 4 years old were kept grassing near copper smelters for long period on clover and feedstuffs periodically sprayed and fertilized by insecticides and fertilizaters containing copper compounds. Thirty five out of 70 adult cattle (50\%) showed clinical signs of chronic copper toxicity in the form of anorexia, emaciation, diarrhoea, haematouria and icterus. Five of the diseased cows were emergency slaughtered. Ten apparently healthy cows housed away from sources of pollution were chosen as control group.

\section{Sampling:}

Water, soil and feedstuff (clover \& concentrated ration) samples were collected in clean containers for estimation of its copper content by using the atomic absorption spectrophotometer (PYE-Unicum, SP-90, England) after Khan et al. (1995).

Tissues Samples: 5 grams from liver, kidney, spleen and muscles were collected from slaughtered animals for estimation of copper residues by using atomic absorption spectrophotometer according to Berman (1980).

Blood samples: Two blood samples were taken from jugular vein of diseased and control cows. The first one collected into $20 \mathrm{ml}$ test tubes to obtain clear non haemolysed serum for estimation of copper, sodium, potassium, zinc and iron by atomic absorption spectrophotometer (Khan 
et al. 1995). Total protein, albumin according to King and Watton (1959). Serum urea (Patton and Crouch, 1977). Creatinine (Brod \& Sirota, 1978). Liver enzymatic activities of serum aspatate aminotransferase (S.AST) and serum alanine aminotransferase (S.ALT) according to Reitman and Frankel (1957). Alkaline phosphatase activity (Kind \& King, 1954). The second blood samples were collected into $10 \mathrm{ml}$ heparinized evacuated tubes for haematological analysis of erythrocytic count (RBCs), haemoglobin conten (Hb), haematocrit value (PCV\%). Total and differential leucocytic count according to Coles (1988).

\section{Statistical analysis:}

The obtained data were statistically analysed according to the method described by Selvin (1996)

\section{RESULTS}

Samples of water, soil and Feedstuffs of the polluted locations in our study showed highly significant $(\mathrm{P}<0.01)$ increase in copper level than the permissible limits of WHO (1995), Table (1). The serum of the diseased cattle with chronic copper poisoning revealed significant increase $(\mathrm{P}<0.01)$ in copper level. Also, copper residues in tissues of emergency slaughtered cows indicated also a highly significant increase $(\mathrm{P}<0.01)$. Simple positive correlation coefficient was recorded between copper content in sources of pollution (water, soil, diet), blood and tissues. (Table, 4).

The effect of chronic cooper poisoning on serum biochemical and haematological parameters were recorded in Table (2, 3). 
Environmental Pollution With Copper And Its ...

Table (1): Copper concentration in examined samples of water, soil, feedstuffs, blood and tissues (ppm).

\begin{tabular}{|c||c||c||}
\hline Samples & $\begin{array}{c}\text { Normal guidline } \\
\text { levels }(\text { WHO, 1995) }\end{array}$ & $\begin{array}{c}\text { Examined polluted samples } \\
\text { Mean } \pm \text { SE. }\end{array}$ \\
\hline \hline Water & $1.00 \mathrm{ppm}$ & $25.0 \pm 5.21$ \\
\hline Soil & $5.00 \mathrm{ppm}$ & $85.0 \pm 8.72$ \\
\hline Clover & $3-10 \mathrm{ppm}$ & $35.0 \pm 3.12$ \\
\hline Con. Ration & $1-10 \mathrm{ppm}$ & $45.0 \pm 10.52$ \\
\hline Blood & $85.0 \pm 5.22$ & $210 \pm 18.35$ \\
\hline Liver & $10.0 \pm 2.15$ & $132.0 \pm 18.21$ \\
\hline Kidney & $8.0 \pm 2.35$ & $85.0 \pm 5.15$ \\
\hline Spleen & $5.0 \pm 1.15$ & $45.0 \pm 3.35$ \\
\hline Museles & $3.0 \pm 0.75$ & $22.0 \pm 6.72$ \\
\hline \hline
\end{tabular}

Table (2): Haematological changes in blood of diseased cattle due to copper toxicity.

\begin{tabular}{||c||c|c||}
\hline Parameters & $\begin{array}{c}\text { Control } \\
\text { healthy cattle }\end{array}$ & Diseased cattle \\
\hline \hline RBCs 106/ul & $7.8 \pm 0.12$ & $5.6 \pm 0.22^{* *}$ \\
\hline Hb. Gm\% & $10.0 \pm 0.75$ & $7.2 \pm 0.53^{* *}$ \\
\hline PCV \% & $36.0 \pm 1.22$ & $26.3 \pm 2.24^{* *}$ \\
\hline MCV FL & $45.0 \pm 3.15$ & $39.0 \pm 2.32$ \\
\hline MCH Pg & $18.0 \pm 2.35$ & $15.0 \pm 1.25$ \\
\hline MCHC \% & $47.0 \pm 1.85$ & $42.0 \pm 2.15$ \\
\hline WBCs 103/ul & $18.0 \pm 1.27$ & $25.0 \pm 2.72^{* *}$ \\
\hline Lymphocytes \% & 38.2 & $48.5^{* *}$ \\
\hline Neutrophils \% & 52.3 & $45.5^{* *}$ \\
\hline Eosinophils \% & 3.2 & $1.5^{*}$ \\
\hline Basophils \% & 2.8 & $1.8^{* *}$ \\
\hline Monocytes \% & 3.5 & $2.7^{*}$ \\
\hline * Significant at (P < 0.05). & & Highly Significant at $(\mathrm{P}<0.01)$. \\
\hline
\end{tabular}

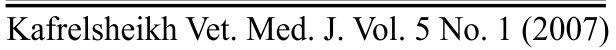


Anwaar, M. Abdel-Azeem \& Attia, $H$.

Table (3): Biochemica changes of clinically healthy and diseased cattle with chronic copper poisoning.

\begin{tabular}{|c|c|c|c|}
\hline \multicolumn{2}{|c|}{ Parameters } & Clinically & Diseased cattle \\
\hline Serum copper & ug/dl & $85.0+5.22$ & $210.0+18.35^{* *}$ \\
\hline S.AST & IU/dl & $48.0+4.77$ & $112.25+7.15^{* *}$ \\
\hline S.ALT & IU/dl & $25.0+2.55$ & $88.0+5.25 * *$ \\
\hline S.AP & $\mathrm{KAU} / \mathrm{dl}$ & $35.0+1.75$ & $65.0+3.22 *$ \\
\hline S.Total protein & $\mathrm{gm} / \mathrm{dl}$ & $7.5+0.24$ & $5.2+0.32 *$ \\
\hline Albumin & $\mathrm{gm} / \mathrm{dl}$ & $3.8+0.12$ & $2.2+0.12^{*}$ \\
\hline Globulin & $\mathrm{gm} / \mathrm{dl}$ & $3.7+0.12$ & $3.0+0.20 *$ \\
\hline Sodium & $\mathrm{mEq} / \mathrm{L}$ & $135.0+7.22$ & $77.0+5.21 * *$ \\
\hline Potassium & $\mathrm{mEq} / \mathrm{L}$ & $5.2+0.33$ & $3.0+0.25^{*}$ \\
\hline Zinc & ug/dl & 135.09 .21 & $150.0+8.75^{* *}$ \\
\hline Iron & ug/dl & $128.0+7.55$ & $175.0+9.88^{* *}$ \\
\hline Serum urea & mg\% & $25.0+2.52$ & $36.0+2.15 * *$ \\
\hline Creatinine & $\mathrm{mg} \%$ & $1.25+0.05$ & $2.2+0.12^{*}$ \\
\hline
\end{tabular}

* Significant at $(\mathrm{P}<0.05)$.

** Highly Significant at $(\mathrm{P}<0.01)$.

Table (4): Simple correlation coefficient of copper contents in all examined samples.

\begin{tabular}{|c|c|c|c|c|c|c|}
\hline & Water & Soil & Clover & $\begin{array}{l}\text { Conc. } \\
\text { Ration }\end{array}$ & $\begin{array}{l}\text { Blood } \\
\text { serum }\end{array}$ & Tissues \\
\hline Water & + & & & & & \\
\hline Soil & + & + & & & & \\
\hline Clover & + & + & + & & & \\
\hline Conc.Ration & + & + & + & + & & \\
\hline Blood & + & + & + & + & + & \\
\hline Tissues & + & + & + & + & + & + \\
\hline
\end{tabular}

(+) Positive correlation.

$\overline{\text { Kafrelsheikh Vet. Med. J. Vol. } 5 \text { No. } 1 \text { (2007) }}$ 


\section{DISCUSSION}

There are many routes of environmental pollution by which copper particles can enter the animal body via contaminated water, soil, plants and crops as a result of man's activities. In the present study, the estimated mean values of copper in the examined samples of water, soil, clover and concentrated ration were highly significant increased $(\mathrm{P}<$ 0.01) than the recommended permissible limits recorded by WHO (1995). This increasing as shown in table (1) could be attributed to the periodical using of insecticide and fungicides sprays, in addition of continuous using of chemical fertilizers containing copper $8 \%$. Moreover, the animal farms in Zagazig areas were adjacent to copper smelters, where winding air carried the exhausted emissions of copper and distributed it all over the neighboring cultivated fields, pastures and feeder streams. These results agreed with those recorded by Clark and Clark (1985), Omran (1997), Radostits et al. (2002) and Eman et al. (2006).

The diseased cows were free from external and internal parasites due to the periodic dosing of anthelmentic drugs, thus the noticed clinical signs were related to the increased copper levels in sources of pollution, blood and tissues of the emergency slaughtered animals as chronic copper poisoning (Table 2). All the diseased cattle showed clinical signs of depression, weakness, anorexia, diarrhoea and haemoglobinurea. Few cases suffered from icterus. The observed clinical signs were similar to those reported by Gmmow et al. (2002) and Preece (2004). These clinical signs were attributed to the positive correlation between the 
highly significant increase of copper levels of water, soil, clover, concentrated ration and serum copper level of diseased cattle and also the increased copper tissues (Table, 4). Virzgula et al. (2005), reported that due to the long term exposure of cattle to polluted water and feedstuffs, the copper is gradually absorbed from the intestine to the circulated blood stream and consequently accumulated in liver till the hepatic level reaches its maximum, the clinical signs of intravascular haemolysis appeared.

The haematological studies in diseased cows with chronic copper as shown in table (2) revealed a marked normocytic normochromic anaemia represented by a significant decrease of total red blood cells count, haemoglobin content and packed cell volume, in addition to the marked leucocytosis. These was attributed to the direct toxic effect of increased copper level in blood which responsible for the excessive destruction and haemolysis of RBCs. These results were agreed with those obtained by Labble (1990), Underwood (2002) and Osuna et al. (2005).

Regarding serum biochemical changes in blood of diseased cows (Table, 3), there were a highly significant increase of copper levels in blood $(\mathrm{P}<0.01)$ when compared with control ones. These was due to increased copper level in water and feedstuffs taken by the cows housed in the polluted area of our study for long periods (Schwarz et al. 2004).

The diseased cattle showed highly significant increase of serum AST, ALT and S.AP enzymatic activities due to the degenerative changes and destructive effects of copper residues on liver, kidneys, intestine and muscles which consequently liberated their intracellular Kafrelsheikh Vet. Med. J. Vol. 5 No. 1 (2007) 
enzymes into the circulatory blood stream Diab (1995) and Linzon (2005) agreed with the result recorded in the present study. The present study revealed a significant increase $(\mathrm{P}<0.01)$ of serum Zinc and Iron in blood of diseased cattle (Table, 3), due to the toxic inhibitory effect of copper residues on Zinc and Iron depended enzymes (Zinc protoporphyrin) and (Delta-aminolevulinic acid dehydraseenzyme), respectively. These results were similar to those reported by Radostits et al. (2002) and Aronson (2004). The diseased cattle also showed hypoproteinaemia and hypalbuminaemia as shown in table (3). These results coincided with those obtained by Meyer and Coenen (1994) and McCosker (2003). These drop of serum protein and albumin may be attributed to the toxic effect of copper on liver tissues resulting in impaired synthesis of albumin and consequently the total protein.

Serum sodium and potassium levels in diseased cattle showed a significant hyponatraemia and hypokalaemia (Table, 3) due to the toxic effect of copper on the renal tubules giving rise to excessive excretion of sodium and potassium in urine (Gummow et al. 2002 and Osuma et al. 2005).

A highly significant increase in serum urea and creatinine levels were recorded in diseased cows with chronic copper toxicity when compared with those of control ones (Table, 3). This elevation was attributed to the nephrotoxic effect of copper to the renal tubules and glomeruli, resulting in the accumulation of urea and creatinine in blood. These results were similar to those obtained by Clark and Clark (1985) and Schwarz et al. (2004). 
The significant increase of copper residues in tissues of emergency slaughtered diseased cattle especially (liver, kidney, spleen and muscles) more than the permissible limits of WHO, (1995) was in agreement with those recorded by Diab (1995) and Underwood (2002), who interpreted such increase to the positive correlation of copper level in blood and its values in tissues (Tables, 1-4).

In conclusion, it was evident that the level of copper in serum provided a reliable indication of chronic copper poisoning of the farm animals supporting the clinical diagnosis of copper poisoning. Hence avoidance of pasture pollution with copper is needed to keep animals in a good healthy status. Moreover, it is recommended to examine meat and its products against heavy metal residues to ensure its safety for human consumption.

\section{REFERENCES}

- Aronson, A.L. (2004). Heavy metal poisoning in Farm animals. Vet. Clin. America, 2 (397).

- Berman, E. (1980). Determination of heavy metals in blood and urine by atomic absorption spectropbotometer. Cambridge. GreatBritian University Press. PP. 68-72.

- Brod, J. and Sirota, J.H. (1978). Renal clearance of endogenious creatinine. J. Clin. Invest. 27 : 645-654.

- Clark, E.G. and Clark, M.L. (1985). Veterinary toxicology $2^{\text {nd }}$ Ed. Bailliere Tindall, P. 75.

- Coles, E.H. (1988). Veterinary Clinical Pathology. $2^{\text {nd }}$ Ed. Pheladelephia, London. 
- Diab, O.M.A. (1995). Chemical constituents of beef-cattle, buffaloes and camels meat. Ph. D. Thesis, Fac. Vet. Med. Cairo University, Egypt.

- Eman LAZ and Abou El-Magd, M.K. (2006). Toxicological studies on some industrial pollutants. Minufiya, Vet. J. Vol. 4, No. 1, April (2006).

- Gummow, B. Botha, C.J, Basson, A.T. and Bastianella, S.S. (2002). Causes of chronic copper poisoning in farm animls in Alabama. Bull. Environ. Contam. Toxicol. 55; 568-573.

- Khan, A.T. Diffay, B.C. Forester, D.M. and Mielke, H.W. (1995). Toxic Jaundic due to copper poisoning. $7^{\text {th }}$ Arab. Vet. Congress, Cairo. Vet. Med. Assoc. 260.

- Kind, P.R.N. and King, E.J. (1954). Colorimetric determination of alkaline phosphatase enzyme. J. Clin. Path, 7 : 32.

- King, E.J. and Watton, I.D. (1959). Microanalysis in medical biochemistry Churchill, L.T.D, London, P. 58.

- Labbe, R.F. (1990). Lead, Cadmium and copper pollution mechanism in farm animals. Clin. Chem. $36: 1870$.

- Linzon, S.N. (2006). Heavy metals environmental pollution. International conference of heavy metals, Amesterdam, Sep. 15-19.

- McCosker, P.J. (2003). Observations on blood copper in Farm animals, Vet. Rec. 108, 114.

- Meyer, H. and Coenen, M. (1994). Copper residues in tissues of ruminant. Deutsche Tieraztiche Wochen Schrift, 101 (1) : 31-33. 
- Omram, H.H. (1997). Environmental pollutin with lead and cadmium and their impact on dairy cattle. Ph. D. Thesis. Fac. Vet. Med. Zag. Univ. Egypt.

- Osuna, O. George, T. Games, A. and Popp. D. (2005). Heavy metals residues in blood, tissues and milk of dairy Farms located in industrial area. Am. J. Vet. Res. 42 : 1542.

- Patton, C.J. and Crouch, S.R. (1977). Determination of blood urea Anal. 49 : 464-469.

- Preece, B.F. (2004). Chronic copper poisoning in Farm animal at Turnout. Vet. Rec., 136 (18) : 475-479.

- Radostits, O.H, Blood, D.C. and Gay, C.C. (2002). Veterinary Medicine $10^{\text {th }}$ Ed. Bailliere, Tindall, London and Pheladelphia, P. 1112-1116.

- Reitman, S. and Frankel, S. (1957). Colorimetric method for determination of serum aspatrate aminotransferase and alanine aminotransferase enzymes. Am. J. Clin. Path., 28 : 56-63.

- Schwarz, L. Anderson, O. and Neilson, J.B. (2004). Factors affecting copper absorption in animal body. Deutche Tieraztiche, Wochen Schrift. 88 (10) : 369.

- Selvin. A.S. (1996). Scientific statistical analysis. Oxford University $2^{\text {nd }}$ Ed. PP. 44-78

- Underwood, E.J. (2002). Trace elements in farm animals. $5^{\text {th }}$. Academic Press. New York. PP. 243-253.

- Virzgula, L.G. Bires, T. and Konard, V. (2005). Copper poisoning in cattle from industrial area. Zivocisnavyroba, 31 : 
463.

- W.H.O “World Health Organization” (1995). Environmental health criteria as standard methods for the evaluation of certain food and water contaminants. Technical Report. Series. 505 (2) Geneva, 280.

التلوث البيئى بمركبات النحاس وتأثثيره على صحة الأبقار فى محافظة الثرقية
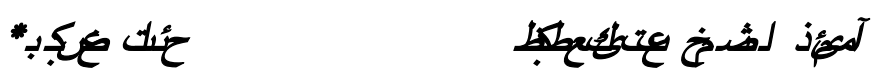

معهد بحوث صحة الحيوان بالدقى فرع الزقازيق - كيمياء ونقص غذائى وسموم " كلية الطب البيطرى جامعة الزقازيق - قسم طب الحيوان

لقد ظهرت حديثا مشكلة التلوث البيئى الخطيرة والتى تصاحب التقدم الصناعى فى العالم مها يجعل البحث عن أسباب التلوث وتأثيره التراكمى على الأبقار التى تعيش وترعى بالقرب من المصانع ومنصهرات النحاس هدفا هاما فى محافظة الثرقية. فى هذه الدراسة تم تجميع عدد 70 بقرة مريضـة تتراوح أعمارها بين 4-6 سنوات وكانت تعيش وترعى فى الحقول والمراعى التى كان يتم رشها دورياً

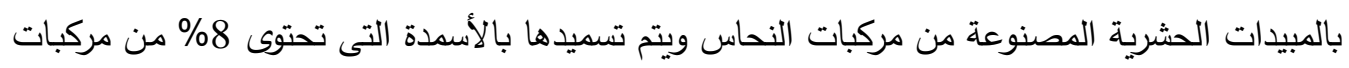

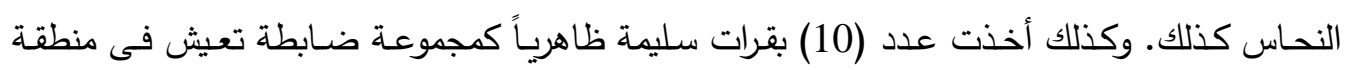
صحراوية بعيدة عن التلوث. بالفحص الإكلينيكى للأبقار المريضـة (70) كانت الأعراض الظاهريـة للتسمم المزمن بالنحاس يتمثل فى فقدان الثهيةو هزال شديد, إسهالات مختلفة مع بول مدمم وإصفرار فـى العين مـع عدم وجـود ارتفـاع فى درجـة الحرارةز وتم التأكد مـن خلوهـا مـن الطفيليات الداخليـة والخارجية وطفيليات الدم نظراً للاستعمال الدورى المنظم للعلاجات المضـادة لهذه الطفيليات. خمس فـ بقرات تم ذبحها إضطرارياً من الأبقار المريضـة موضـع الدراسـة. تم تجميع عينات من المـاء والتربـة 


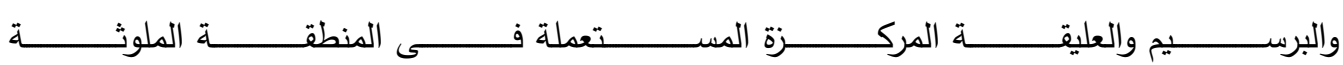

وأوضـحت النتائج إرتفاعـاً ملحوظـاً فـى مستوى عنصـر النحـاس عن معدلات حمايـة البيئة العالميـة (WHO,1995) ) تم تجميع عنيات من دم الأبقار المريضـة والسليمة وأنسجة الأبقار المذبوحة (الكبد والكليتين والطحال والعضـلات) وأوضحت النتائج تتاسباً طردياً فى معدلات النحاس المرتفعة جداً من مصادر التلوث والدم والأنسجة.

وقد أظهرت الفحوص الدموية لتأثير التسمم المزمن بالنحاس على صورة الدم وجود أنيميا حادة متمثلة فى نقص العدد الكلى لكرات الدم الحمراء والهيموجلوبين وحجم خلايا الدم المضغوطة بينما وجد إرتفاعاً ملحوظاً فى عدد خلايا الدم البيضاء. أما الفحوص البيوكيميائية للسيرم أظهرت تأثيراً كبيراً لتسمم المـزمن بالنحـاس على عناصـر الـدم مثل الإرتفـاع المعنـوى فى النشـاط الإنزيمى لخميـرة الأسبرتيت أمينـوترانس فيريز وخميـرة الألانين أمينـوترانس فيريـز وخميـرة الفوسفاتيز القاعدى وكذلك إرتفاعـاً فى مستوى اليوريا والكرياتتين والزنك والحديد بينما وجد نقصاً ملحوظاً فى مستوى البروتين الكلى والألبومين والجلوبيولين والصسوديوم والبوتاسيوم. لذلك يجب أخذ القوانين التى تمنع تربية الأبقار بجوار المصـانع والمنصـهرات النحاسـية والتحذير مـن رعىى هذه الحيوانـات فى المراعى التى يستخدم فيها المبيدات الحشرية والأسمدة الكيماوية التى تحتوى على تركيزات عالية من مركبات النحاس مع وضع التوصيات لمنع هذا التلوث لحماية الثروة الحيوانية فى مصر • 